INOBIS: Jurnal Inovasi Bisnis dan Manajemen Indonesia

Volume 1, Nomor 2, Maret 2018

Sri Dwiningsih, SE., MM

\title{
Analisis Du Pont System untuk Menilai \\ Kinerja Keuangan Perusahaan \\ (Studi Pada Perusahaan Property \& Real Estate LQ45 \\ Yang Terdaftar Di Bursa Efek Indonesia Periode Tahun 2013-2015)
}

\author{
Sri Dwiningsih, SE.,MM \\ Sekolah Tinggi Ilmu Ekonomi Kertanegara Malang (STIEKMA) \\ Alamat Email : sri_dwi76@yahoo.com
}

\begin{abstract}
Abstrak
Perusahaan property $\&$ real estate sangat diminati di Indonesia, tetapi pada 4 tahun terakhir (antara tahun 2014 s/d 2017) perusahaan property \& real estate dari segi pemasaran mengalami penurunan. Tapi kondisi ini tidak menghambat untuk semakin berkembangnya bisnis property di Indonesia.

Melalui analisis laporan keuangan dapat di ketahui kinerja keuangan perusahaan dalam kondisi baik, wajar atau buruk, terdapat kenaikan atau penurunan. Perusahaan harus menilai kondisi dan perkembangan perusahaan melalui laporan keuangan salah satunya dengan alat analisis Du Pont System, sehingga perusahaan mampu mempertahankan bahkan meningkatkan pertumbuhan perusahaan di tengah persaingan yang ketat.

Obyek penelitian ini adalah 6 (enam) perusahaan yang bergerak dalam sektor Property \& Real Estate yang masuk dalam perusahaan LQ45 selama 2 tahun berturut-turut yaitu Pebruari tahun 2015 s/d Januari 2017 untuk periode 2013-2015.

Kesimpulan dari penelitian ini adalah Lippo Karawaci Tbk memiliki hasil ROE terendah yaitu sebesar $11,41 \%$ \& PP (Persero) memiliki hasil ROE tertinggi yaitu sebesar $34,09 \%$. PP (Persero) Tbk menjadi perusahaan dengan kinerja keuangan perusahaan yang paling baik jika dibandingkan dengan perusahaan property \& real estate lain periode tahun 2013-2015. Adapun urutan kinerja yang dihasilkan dari keenam perusahaan property \& real Estate adalah sebagai berikut:

1. (PTPP) Pembangunan Perumahan (Persero) Tbk

2. (PWON) Pakuwon Jati Tbk

3. (BSDE) Bumi Serpong Damai

4. (ASRI) Alam Sutera Reality Tbk

5. (WSKT) Waskita Karya (Persero) Tbk

6. (LPKR) Lippo Karawaci, Tbk
\end{abstract}

Kata Kunci : Du Pont System, LQ45, Property \& Real Estate

\section{Pendahuluan}

Perkembangan dunia usaha di Indonesia sudah mulai meningkat, banyaknya perusahaan baru yang lahir menjadi persaingan yang tajam antar perusahaan. Persaingan ini tidak hanya terdapat di dalam negeri melainkan di luar negeri. Sehingga setiap perusahaan harus mampu bersaing di pasar bebas. Setiap perusahaan memiliki tujuan pokok yaitu memaksimumkan nilai perusahaan demi kelangsungan usahanya. Memaksimalkan nilai perusahaannya yaitu dengan menghasilkan keuntungan sebesar-besarnya dalam jangka waktu yang panjang. Tujuan perusahaan dapat tercapai dengan adanya peningkatan kualitas dan kuantitas perusahaan yang meliputi dari berbagai bidang yang ada pada perusahaan. Adanya 
INOBIS: Jurnal Inovasi Bisnis dan Manajemen Indonesia

Volume 1, Nomor 2, Maret 2018

Sri Dwiningsih, SE., MM

tujuan tersebut yang menjadikan masing-masing pelaku usaha harus bersaing secara kompetitif.

Melalui analisis laporan keuangan dapat di ketahui kinerja keuangan perusahaan dalam kondisi baik, wajar atau buruk, terdapat kenaikan atau penurunan. Analisis laporan keuangan bisa dilakukan menggunakan beberapa alat, salah satunya yaitu dengan menggunakan Du Pont System. Analisis Du Pont System penting bagi Manajer Keuangan untuk mengetahui faktor mana yang paling kuat pengaruhnya antara profit margin dan total asset turnover terhadap ROA. Disamping itu dengan menggunakan analisis ini, pengendalian beban dapat diukur dan efisiensi perputaran asset sebagai akibat turun naiknya penjualan dapat diukur. (Syafarudin 2003:128)

Sistem Du-Pont suatu pendekatan yang dikembangkan oleh Du Pont Company untuk mengukur tingkat efektifitas perusahaan dalam menghasilkan keuntungan serta memutar modalnya. Rasio yang tercangkup dalam Du Pont System ini adalah gabungan antara rasio aktivitas/perputaran aktiva dengan rasio laba/profit margin atas penjualan dan menunjukkan interaksi keduanya dalam menentukan Return On Investment (ROI), yaitu Profitabilitas atas aktiva yang dimiliki perusahaan.

Perusahaan property $\&$ real estate sangat diminati di Indonesia, tetapi pada 4 tahun terakhir (antara tahun 2014 s/d 2017) perusahaan property \& real estate dari segi pemasaran mengalami penurunan. Tapi kondisi ini tidak menghambat untuk semakin berkembangnya bisnis property. Sehingga dalam penelitian ini sampel yg digunakan adalah perusahaan property di Indonesia dimana sahamnya masuk dalam LQ45.

Perusahaan yang terpilih sebagai obyek penelitian adalah 6 (enam) perusahaan yang bergerak dalam sektor Property \& Real Estate yang masuk dalam perusahaan LQ45 selama 2 tahun berturut-turut yaitu Pebruari tahun 2015 s/d Januari 2017.

Perusahaan sebaiknya mengetahui kondisi kinerja agar untuk kedepannya kinerja perusahaan menjadi lebih baik lagi dari tahun sebelumnya dan laba yang dicapai juga akan maksimal. Setiap perusahaan mempunyai kelebihan/keunggulan dan juga mempunyai kelemahan dalam setiap produk yang dimilikinya. Dengan adanya perusahaan yang sejenis membuat perusahaan harus mampu bersaing dan mencapai tujuan utamanya. Selain itu perusahaan harus menilai kondisi dan perkembangan perusahaan melalui laporan keuangan dengan alat analisis Du Pont System, sehingga perusahaan mampu mempertahankan bahkan meningkatkan pertumbuhan perusahaan di tengah persaingan yang ketat.

Melalui analisis Du Pont System, dapat menilai kinerja keuangan dari 6 (enam) perusahaan tersebut dan pada akhirnya dapat dibandingkan perusahaan yang menghasilkan tingkat keuntungan yang tinggi.

\section{Rumusan masalah}

"Bagaimana kinerja keuangan perusahaan pada perusahaan Property \& Real Estate LQ45 yang terdaftar di Bursa Efek Indonesia periode Tahun 2013-2015 jika diukur dengan Du Pont System?"

\section{Landasan teori}

Dari beberapa macam rasio keuangan yang ada, tidak semua rasio yang digunakan dalam analisis Du Pont System, adapun rasio yang digunakan adalah rasio profitabilitas dan rasio aktivitas. Berikut penjelasan dari rasio Du Pont System:

1) Marjin Laba Bersih/Net Profit Margin (NPM) 
INOBIS: Jurnal Inovasi Bisnis dan Manajemen Indonesia

Volume 1, Nomor 2, Maret 2018

Sri Dwiningsih, SE., MM

Marjin laba bersih adalah ukuran profitabilitas perusahaan dari penjualan setelah memperhitungkan semua biaya dan pajak penghasilan (Horne and Wachowicz, 2009), yang dapat diketahui dengan rumus sebagai berikut :

$$
\mathrm{NPM}=\frac{\text { laba bersih setelah pajak }}{\text { penjualan bersih }}
$$

2) Perputaran Total Aktiva/Total Asset Turnover (TATO)

Perputaran total aset merupakan cerminan efisiensi relative penggunaan aset perusahaan untuk menghasilkan penjualan (Horne and Wachowicz, 2009), yang dapat diketahui melalui rumus berikut :

$$
\text { TATO }=\frac{\text { pen jualan bersih }}{\text { total aktiva }}
$$

3) Tingkat Pengembalian atas Investasi/Return On Investment (ROI)

Tingkat pengembalian atas investasi merupakan kelompok dari rasio profitabilitas yang menghubungkan laba dengan investasi penghasilan (Horne and Wachowicz, 2009), yang dapat diketahui melalui rumus berikut :

$$
\begin{aligned}
\mathrm{ROI} & =\frac{\text { laba bersih setelah pajak }}{\text { total aktiva }} \\
\mathrm{ROI}(\text { Du Pont }) & =\mathrm{NPM} \mathrm{x} \text { TATO } \\
& =\frac{\text { Laba bersih setelah pajak }}{\text { penjualan bersih }} \times \frac{\text { Penjualan Bersih }}{\text { Total Aktiva }}
\end{aligned}
$$

4) Tingkat Pengembalian atas ekuitas/Return On Equity (ROE)

Tingkat pengembalian atas ekuitas merupakan rasio yang menunjukkan seberapa besar perusahaan dapat menghasilkan laba atau keuntungan dari hasil pengelolaan modal (Horne and Wachowicz, 2009), yang dapat diketahui melalui rumus berikut :

EM (Equity Multiplier) $=\frac{\text { total aktiva }}{\text { total Modal }}$

ROE (Du Pont) = ROI (Du Pont) $\mathrm{x}$ EM

\section{Kerangka pemikiran}

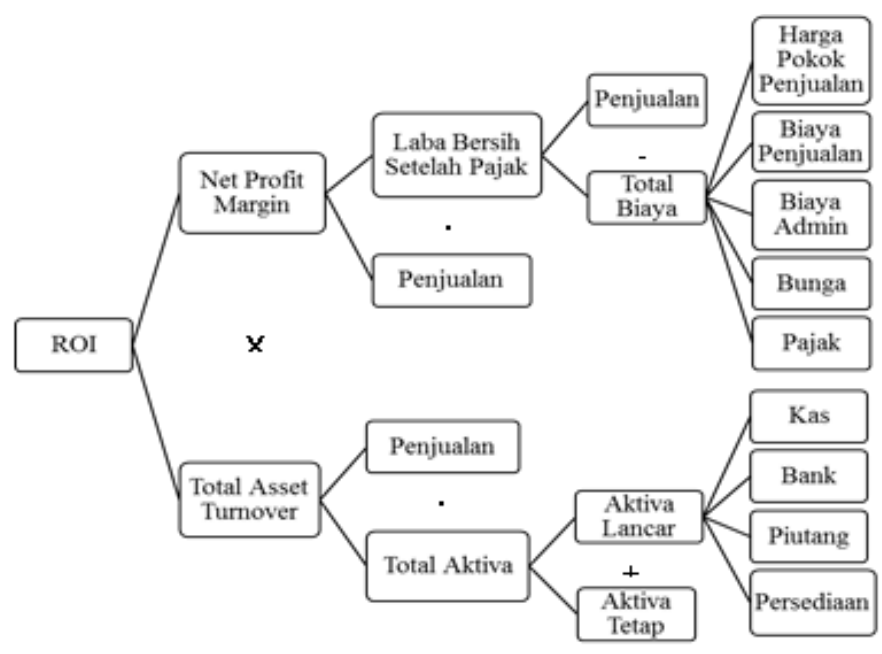

Gambar 1

Sumber : Brigham (2010: 153) 
INOBIS: Jurnal Inovasi Bisnis dan Manajemen Indonesia

Volume 1, Nomor 2, Maret 2018

Sri Dwiningsih, SE., MM

Keterangan :

ROE $\quad$ : Return On Equity / Hasil Pengembalian Ekuitas

ROI : Return On Investment / Hasil Pengembalian Investasi

Equity Multiplier(EM): Pengganda Ekuitas

NPM

: Net Profit Margin / Margin Laba Bersih

TATO

Total Assets : : Total Aktiva

Total Equity : Total Ekuitas / Modal

EAT : Earning After Tax / Laba Bersih Setelah Pajak

Sales : Penjualan

Total Cost : Total Biaya

Current Assets : Aktiva Lancar

Fixed Assets : Aktiva Tetap

\section{Metode penelitian}

Ruang lingkup dalam penelitian ini adalah Analisis Du Pont System sebagai salah satu alat analisis laporan keuangan guna mengukur kinerja keuangan perusahaan. Adapun laporan keuangan yang akan diukur yakni laporan neraca dan laba/rugi dari 6 (enam) perusahaan yang bergerak dalam sektor Property \& Real Estate yang masuk dalam perusahaan Property \& Real Estate LQ45 yang terdaftar di Bursa Efek Indonesia periode Tahun 2013-2015.

\section{A. Lokasi dan waktu penelitian}

Lokasi untuk dilaksanakannya penelitian ini berlokasi di Bursa Efek Indonesia (BEI). Dengan melakukan browsing di alamat website www.idx.co.id. Adapun waktu yang dilakukan untuk penelitian ini dilakukan kurang lebih 3 bulan terhitung mulai bulan Pebruari 2017 s/d April 2017.

\section{Definisi Konseptual Variabel}

\section{a. Analisis}

Analisis adalah kegiatan berfikir untuk menguraikan suatu keseluruhan menjadi komponen sehingga dapat mengenal tanda-tanda komponen, hubungannya satu sama lain dan fungsi masing-masing dalam satu keseluruhan yang terpadu.

\section{b. Du Pont System}

Analisis Du Pont System menurut Brigham (2010:153) merupakan rumus yang menunjukkan tingkat pengembalian aktiva yang dapat diperoleh dari perkalian marjin laba bersih (Net Profit Margin) dengan perputaran total aset (Total Assets Turnover).

\section{c. Kinerja Keuangan}

Sawir (2005:1) mengemukakan kinerja keuangan adalah kondisi yang menunjukkan suatu keadaan keuangan sebuah perusahaan yang berdasarkan atas standar, sasaran dan juga kriteria yang sudah ditetapkan. 
INOBIS: Jurnal Inovasi Bisnis dan Manajemen Indonesia

Volume 1, Nomor 2, Maret 2018

Sri Dwiningsih, SE., MM

\section{d. Perusahaan LQ45 yang Terdaftar di BEI}

LQ45 merupakan suatu forum yang didalamnya berisi perusahaan-perusahaan yang saham-sahamnya memiliki tingkat likuiditas dan kapitalisasi pasar yang tinggi. Tidak sembarang perusahaan yg dapat masuk dalam kriteria LQ45. Perusahaanperusahaan yang ingin masuk dalam daftar LQ45 harus memiliki berbagai kriteria yang harus dipenuhi, antara lain:

1. Saham tersebut harus masuk dalam rangking 60 besar dari total transaksi saham di pasar reguler (yang dilihat adalah rata-rata nilai transaksi selama 12 bulan terakhir)

2. Saham tersebut juga harus masuk ke dalam jajaran teratas dalam peringkat berdasarkan kapitalisasi pasar (yang dilihat adalah rata-rata kapitalisasi pasar selama 12 bulan terakhir)

3. Saham tersebut harus tercatat di Bursa Efek Indonesia (BEI) selama minimum 3 bulan.

4. Keadaan keuangan perusahaan dan prospek pertumbuhan dari perusahaan pemilik saham harus baik begitu juga frekuensi dan jumlah hari perdagangan transaksi di pasar regulernya juga harus baik

\section{Definisi Operational Variabel}

Tabel 1 Definisi Operational Variabel

\begin{tabular}{|c|c|c|c|}
\hline Variabel & Definisi & Indikator & Skala \\
\hline $\begin{array}{l}\text { Net Profit } \\
\text { Margin (NPM) }\end{array}$ & $\begin{array}{l}\text { ukuran keuntungan dengan membandingkan antara } \\
\text { laba setelah bunga dan pajak dibandingkan dengan } \\
\text { penjualan }\end{array}$ & $\frac{E A T}{\text { Sales }}$ & Rasio \\
\hline $\begin{array}{l}\text { Total Assets } \\
\text { Turnover } \\
\text { (TATO) }\end{array}$ & $\begin{array}{l}\text { rasio yang digunakan untuk mengukur perputaran } \\
\text { semua aktiva yang dimiliki perusahaan dan } \\
\text { mengukur berapa jumlah penjualan yang diperoleh } \\
\text { dari tiap rupiah aktiva }\end{array}$ & $\frac{\text { sales }}{\text { Total Assets }}$ & Rasio \\
\hline $\begin{array}{l}\text { Return On } \\
\text { Investment } \\
\text { (ROI) }\end{array}$ & $\begin{array}{l}\text { rasio yang menunjukkan hasil (return) atas jumlah } \\
\text { aktiva yang digunakan dalam perusahaan }\end{array}$ & $\begin{array}{l}\frac{E A T}{T . \text { Assets }} \\
\text { ROI Du Pont: } \\
\text { NPM x TATO }\end{array}$ & Rasio \\
\hline $\begin{array}{l}\text { Equity } \\
\text { Multiplier } \\
\text { (EM) }\end{array}$ & $\begin{array}{l}\text { rasio yang menunjukkan kemampuan perusahaan } \\
\text { dalam mendayagunakan ekuitas pemegang saham }\end{array}$ & $\frac{\text { Total Assets }}{\text { Equity }}$ & Rasio \\
\hline $\begin{array}{l}\text { Return On } \\
\text { Equity (ROE) } \\
\text { Du Pont }\end{array}$ & $\begin{array}{l}\text { Du Pont yang diperluas, memperlihatkan } \\
\text { bagaimana utang, perputaran aktiva dan profit } \\
\text { margin dikombinasikan untuk menentukan return } \\
\text { on equity (ROE). }\end{array}$ & $\begin{array}{c}\text { ROE Du Pont } \\
= \\
\text { ROI x EM }\end{array}$ & Du Pont \\
\hline
\end{tabular}

Sumber : Data diolah, 2017 
INOBIS: Jurnal Inovasi Bisnis dan Manajemen Indonesia

Volume 1, Nomor 2, Maret 2018

Sri Dwiningsih, SE., MM

\section{B. Populasi dan sampel}

Populasi dalam penelitian ini yaitu 6 (enam) perusahaan yang bergerak dalam sektor Property \& Real Estate yang masuk dalam perusahaan LQ45 selama 2 tahun berturut-turut yaitu Pebruari tahun 2015 s/d Januari 2017

Berdasarkan hal tersebut peneliti menetapkan 6 (enam) perusahaan yang dapat dijadikan sampel penelitian diantaranya adalah:

1. (ASRI) Alam Sutera Reality Tbk

2. (BSDE) Bumi Serpong Damai

3. (LPKR) Lippo Karawaci, Tbk

4. (PTPP) Pembangunan Perumahan (Persero) Tbk

5. (PWON) Pakuwon Jati Tbk

6. (WSKT) Waskita Karya (Persero) Tbk

\section{Hasil dan pembahasan}

Informasi yang disajikan dalam laporan keuangan mempunyai peranan yang cukup penting dalam usaha penilaian terhadap perkembangan suatu perusahaan. Namun laporan keuangan yang disajikan oleh perusahaan harus diolah kembali sehingga mempermudah pihak yang berkepentingan dalam membaca laporan keuangan tersebut yaitu dengan cara dianalisa.

Untuk dapat menganalisis laporan keuangan pada perusahaan diperlukan laporan keuangan yang terdiri dari neraca dan laporan laba rugi tahun 2013 - 2015 dari perusahaan yang menjadi obyek penelitian yaitu perusahaan property \& real Estate LQ45. Data-data tersebut diklasifikasikan dan dihitung rasio keuangan sesuai dengan rasio yang terkandung dalam analisis $D u$ Pont untuk mendapatkan penilaian kinerja perusahaan tersebut.

Berikut adalah langkah-langkah dalam analisis $D u$ Pont System menggunakan Metode Time Series Analysis

\section{1) Net Profit Margin (NPM)}

Net Profit Margin adalah rasio profitabilitas yang digunakan untuk mengetahui pendapatan bersih perusahaan atas penjualan. Rasio ini dapat dilakukan dengan cara membandingkan antara laba setelah bunga dan pajak dengan penjualan. NPM dapat diketahui dengan rumus sebagai berikut :

Net Profit Margin $=\underline{\text { EAT }(\text { Laba Bersih Setelah Pajak })} \times 100 \%$

Penjualan Bersih

Tabel 2 Hasil Perhitungan Net Profit Margin (NPM)

\begin{tabular}{lrrrr}
\hline \multirow{2}{*}{ Perusahaan } & \multicolumn{4}{c}{ NPM } \\
\cline { 2 - 5 } & 2013 & 2014 & 2015 & Rata-rata \\
\hline Alam Sutra Reality. Tbk & $24,15 \%$ & $32,41 \%$ & $24,58 \%$ & $27,05 \%$ \\
\hline Bumi Serpong Damai & $50,61 \%$ & $71,73 \%$ & $37,87 \%$ & $53,40 \%$ \\
\hline Lippo Karawaci. Tbk & $25,71 \%$ & $11,49 \%$ & $6,58 \%$ & $20,78 \%$ \\
\hline PP (Persero) & $6,58 \%$ & $7,40 \%$ & $9,06 \%$ & $7,68 \%$ \\
\hline Pakuwon Jati. Tbk & $37,51 \%$ & $67,12 \%$ & $30,28 \%$ & $44,97 \%$ \\
\hline Waskita Karya (Persero) Tbk & $3,80 \%$ & $4,87 \%$ & $7,40 \%$ & $5,36 \%$ \\
\hline
\end{tabular}


INOBIS: Jurnal Inovasi Bisnis dan Manajemen Indonesia

Volume 1, Nomor 2, Maret 2018

Sri Dwiningsih, SE., MM

\begin{tabular}{llll}
\hline Rata-rata $24,63 \%$ & $34,87 \%$ & $20,11 \%$ \\
\hline
\end{tabular}

Sumber : Data sekunder yang sudah diolah (2017)

Berdasarkan tabel di atas, dapat disimpulkan bahwa hasil NPM Bumi Serpong Damai yg paling besar yaitu senilai 53,40\% sedangkan hasil NPM terkecil adalah Waskita Karya (Persero) Tbk yaitu senilai 5,36\%. Dalam hal ini Bumi Serpong Damai adalah perusahaan yang sangat memuaskan kinerja keuangannya yang hasilnya lebih besar dari rata-rata industry property \& real estate yang lain.

\section{2) Total Assets Turnover (TATO)}

Perputaran total aktiva menunjukkan tingkat efisiensi penggunaan aset perusahaan untuk menghasilkan penjualan. Adapun hasil perhitungan Total Assets Turnover (TATO)/ perputaran total aktiva 6 (enam) perusahaan yang bergerak dalam sektor Property \& Real Estate yang masuk dalam perusahaan LQ45 selama 2 tahun berturut-turut yaitu Pebruari tahun 2015 s/d Januari 2017 periode 2013 - 2015 adalah sebagai berikut :

Tabel 3 Hasil Perhitungan Total Assets Turnover (TATO)

\begin{tabular}{lcccr}
\hline \multirow{2}{*}{\multicolumn{1}{c}{ Perusahaan }} & \multicolumn{5}{c}{ TATO } \\
\cline { 2 - 5 } & 2013 & 2014 & 2015 & Rata-rata \\
\hline Alam Sutra Reality. Tbk & 0,255 & 0,215 & 0,149 & 0,206 \\
\hline Bumi Serpong Damai & 0,254 & 0,198 & 0,172 & 0,208 \\
\hline Lippo Karawaci. Tbk & 0,213 & 0,309 & 0,216 & 0,246 \\
\hline PP (Persero) & 0,939 & 0,850 & 0,743 & 0,844 \\
\hline Pakuwon Jati. Tbk & 0,326 & 0,231 & 0,246 & 0,268 \\
\hline Waskita Karya (Persero) Tbk & 1,102 & 0,820 & 0,467 & 0,796 \\
\hline Rata-rata & 0,515 & 0,437 & 0,332 & \\
\hline Sumber : Data sekunder yang sudah diolah $(2017)$ &
\end{tabular}

Berdasarkan tabel diatas, perputaran total aktiva seluruh perusahaan cenderung mengalami fluktuasi atau ketidakstabilan dari tahun 2013-2015. Namun dari hasil tersebut Alam Sutra Reality. Tbk menjadi perusahaan dengan hasil TATO terendah yaitu sebesar 0,206 dari beberapa perusahaan sejenis. Sedangkan hasil tertinggi dicapai oleh PP (Persero) yaitu sebesar 0,844. Sehingga dapat dikatakan bahwa perusahaan dengan TATO terendah kurang efisien dalam menggunakan seluruh total aktiva untuk menghasilkan volume penjualan.

\section{3) Return On Investment (ROI) Du Pont}

Pengembalian atas investasi/Return On Investment (ROI) menunjukkan daya untuk menghasilkan laba perusahaan. Berikut hasil perhitungan nilai ROI (Return On Investmen)/ pengembalian atas investasi 6 (enam) perusahaan yang bergerak dalam sektor Property \& Real Estate yang masuk dalam perusahaan LQ45 selama 2 tahun berturut-turut yaitu Pebruari tahun 2015 s/d Januari 2017 periode 2013-2015: 
INOBIS: Jurnal Inovasi Bisnis dan Manajemen Indonesia

Volume 1, Nomor 2, Maret 2018

Sri Dwiningsih, SE., MM

Tabel 4 Hasil Perhitungan Return On Investment (ROI) Du Pont

\begin{tabular}{lrrrr}
\hline \multirow{2}{*}{ Perusahaan } & \multicolumn{4}{c}{ ROI } \\
\cline { 2 - 5 } & 2013 & 2014 & 2015 & Rata-rata \\
\hline Alam Sutra Reality. Tbk & $6,17 \%$ & $6,95 \%$ & $3,66 \%$ & $5,59 \%$ \\
\hline Bumi Serpong Damai & $12,87 \%$ & $14,20 \%$ & $6,53 \%$ & $11,20 \%$ \\
\hline Lippo Karawaci. Tbk & $5,36 \%$ & $7,49 \%$ & $2,48 \%$ & $5,26 \%$ \\
\hline PP (Persero) & $6,18 \%$ & $6,29 \%$ & $6,73 \%$ & $6,40 \%$ \\
\hline Pakuwon Jati. Tbk & $12,22 \%$ & $15,50 \%$ & $7,46 \%$ & $11,73 \%$ \\
\hline Waskita Karya (Persero) Tbk & $4,19 \%$ & $4,00 \%$ & $3,46 \%$ & $3,88 \%$ \\
\hline Rata-rata & $7,83 \%$ & $9,15 \%$ & $5,05 \%$ & \\
\hline Sumber : Data seku
\end{tabular}

Sumber : Data sekunder yang sudah diolah (2017)

Berdasarkan dari hasil perhitungan ROI di atas, diketahui hasil ROI terendah Waskita Karya (Persero) Tbk yaitu sebesar 3,88\% dan yang tertinggi adalah Pakuwon Jati. Tbk yaitu sebesar $11,73 \%$

Dilihat dari nilai ROI keenam perusahaan tersebut, dapat disimpulkan bahwa Waskita Karya (Persero) Tbk mempunyai tingkat pengembalian yang paling rendah atas nilai yang diinvestasikan dalam aktiva guna memperoleh laba. Sedangkan Pakuwon Jati. Tbk dinyatakan mempunyai kinerja keuangan yang baik sebab nilai ROI berada di atas rata-rata perusahaan property \& real estate yang lain walaupun nilai setiap tahunnya dari tahun 20132015 mengalami ketidakstabilan/fluktuasi.

\section{4) Return On Equity (ROE) Du Pont}

Pengembalian atas ekuitas merupakan rasio yang menunjukkan seberapa besar perusahaan dapat menghasilkan laba atau keuntungan dari hasil pengelolaan modal.Rasio ini mencerminkan penerimaan perusahaan atas peluang investasi yang baik dan manajemen biaya yang efektif.Untuk menghitung ROE dalam analisis Du Pont ini terlebih dahulu harus menghitung besarnya Equity Multiplier dari tiap-tiap perusahaan. Berikut hasil perhitungan Equity Multiplier periode 2013-2015:

Tabel 5 Hasil Perhitungan Equity Multiplier (EM)

\begin{tabular}{lcccr}
\hline \multirow{2}{*}{ Perusahaan } & \multicolumn{4}{c}{ Equity Multiplier (EM) } \\
\cline { 2 - 5 } & 2013 & 2014 & 2015 & Rata-rata \\
\hline Alam Sutra Reality. Tbk & 2,706 & 2,656 & 2,834 & 2,732 \\
\hline Bumi Serpong Damai & 1,683 & 1,523 & 1,630 & 1,612 \\
\hline Lippo Karawaci. Tbk & 2,208 & 2,140 & 2,185 & 2,177 \\
\hline PP (Persero) & 6,256 & 6,113 & 3,737 & 5,368 \\
\hline Pakuwon Jati. Tbk & 2,255 & 2,025 & 1,986 & 2,092 \\
\hline Waskita Karya (Persero) Tbk & 3,687 & 4,403 & 3,123 & 3,738 \\
\hline Rata-rata & 3,134 & 3,143 & 2,582 & \\
\hline
\end{tabular}

Sumber : Data sekunder yang sudah diolah (2017)

Dengan adanya hasil Equity Multiplier diatas, maka dapat menghitung besarnya ROE dengan cara mengalikan ROI dengan Equity Multiplier. Sehingga dapat diketahui nilai ROE untuk 6 perusahaan tersebut. Adapun hasil dari perhitungan ROE adalah sebagai berikut: 
INOBIS: Jurnal Inovasi Bisnis dan Manajemen Indonesia

Volume 1, Nomor 2, Maret 2018

Sri Dwiningsih, SE., MM

Tabel 6 Hasil Perhitungan Return On Equity (ROE) Du Pont

\begin{tabular}{lcccr}
\hline \multirow{2}{*}{\multicolumn{1}{c}{ Perusahaan }} & \multicolumn{4}{c}{ ROE } \\
\cline { 2 - 5 } & 2013 & 2014 & 2015 & Rata-rata \\
\hline Alam Sutra Reality. Tbk & $16,68 \%$ & $18,47 \%$ & $10,36 \%$ & $15,17 \%$ \\
\hline Bumi Serpong Damai & $21,66 \%$ & $21,63 \%$ & $10,64 \%$ & $17,98 \%$ \\
\hline Lippo Karawaci. Tbk & $11,82 \%$ & $16,98 \%$ & $5,41 \%$ & $11,41 \%$ \\
\hline PP (Persero) & $38,64 \%$ & $38,47 \%$ & $25,15 \%$ & $34,09 \%$ \\
\hline Pakuwon Jati. Tbk & $27,70 \%$ & $31,38 \%$ & $14,81 \%$ & $24,63 \%$ \\
\hline Waskita Karya (Persero) Tbk & $15,44 \%$ & $17,59 \%$ & $10,80 \%$ & $14,61 \%$ \\
\hline Rata-rata & $21,99 \%$ & $24,09 \%$ & $12,86 \%$ & \\
\hline
\end{tabular}

Sumber : Data sekunder yang sudah diolah (2017)

Berdasarkan dari hasil ROE diatas, dapat dilihat hasil dari perbandingan keenam perusahaan property \& real estate dapat disimpulkan bahwa Lippo Karawaci Tbk memiliki hasil terendah yaitu sebesar $11,41 \%$ \& PP (Persero) memiliki hasil tertinggi yaitu sebesar $34,09 \%$.

Dari perhitungan yang sudah dilakukan, dapat disimpulkan menggunakan tabel hasil rekapan, sehingga memudahkan dapat menarik kesimpulan penilaian kinerja keuangan perusahaan. Hasil perhitungan adalah sebagai berikut: 
INOBIS: Jurnal Inovasi Bisnis dan Manajemen Indonesia

Volume 1, Nomor 2, Maret 2018

Sri Dwiningsih, SE., MM

Tabel 7

Hasil Perhitungan Analisis Du Pont System 6 (enam) perusahaan Property \& Real Estate LQ45 selama 2 tahun berturut-turut Pebruari tahun 2015 s/d Januari 2017 Periode Tahun 2013-2015

\begin{tabular}{|c|c|c|c|c|c|c|c|c|c|c|c|c|c|c|c|}
\hline \multirow{2}{*}{ Perusahaan } & \multicolumn{3}{|c|}{ NPM (\%) } & \multicolumn{3}{|c|}{ TATO (x) } & \multicolumn{3}{|c|}{ ROI Du Pont(\%) } & \multicolumn{3}{|c|}{ Equity Multiplier(x) } & \multicolumn{3}{|c|}{ ROE Du Pont (\%) } \\
\hline & 2013 & 2014 & 2015 & 2013 & 2014 & 2015 & 2013 & 2014 & 2015 & 2013 & 2014 & 2015 & 2013 & 2014 & 2015 \\
\hline Alam Sutra Reality. Tbk & $24,15 \%$ & $32,41 \%$ & $24,58 \%$ & 0,255 & 0,215 & 0,149 & $6,17 \%$ & $6,95 \%$ & $3,66 \%$ & 2,706 & 2,656 & 2,834 & $16,68 \%$ & $18,47 \%$ & $10,36 \%$ \\
\hline Bumi Serpong Damai & $50,61 \%$ & $71,73 \%$ & $37,87 \%$ & 0,254 & 0,198 & 0,172 & $12,87 \%$ & $14,20 \%$ & $6,53 \%$ & 1,683 & 1,523 & 1,630 & $21,66 \%$ & $21,63 \%$ & $10,64 \%$ \\
\hline PP (Persero) & $6,58 \%$ & $7,40 \%$ & $9,06 \%$ & 0,939 & 0,850 & 0,743 & $6,18 \%$ & $6,29 \%$ & $6,73 \%$ & 6,256 & 6,113 & 3,737 & $38,64 \%$ & $38,47 \%$ & $25,15 \%$ \\
\hline Pakuwon Jati. Tbk & $37,51 \%$ & $67,12 \%$ & $30,28 \%$ & 0,326 & 0,231 & 0,246 & $12,22 \%$ & $15,50 \%$ & $7,46 \%$ & 2,255 & 2,025 & 1,986 & $27,70 \%$ & $31,38 \%$ & $14,81 \%$ \\
\hline $\begin{array}{l}\text { Waskita Karya (Persero) } \\
\text { Tbk }\end{array}$ & $3,80 \%$ & $4,87 \%$ & $7,40 \%$ & 1,102 & 0,820 & 0,467 & $4,19 \%$ & $4,00 \%$ & $3,46 \%$ & 3,687 & 4,403 & 3,123 & $15,44 \%$ & $17,59 \%$ & $10,80 \%$ \\
\hline Rata - rata Industri & $24,63 \%$ & $34,87 \%$ & $20,11 \%$ & 0,515 & 0,437 & $\mathbf{0 , 3 3 2}$ & $7,83 \%$ & $9,15 \%$ & $5,05 \%$ & 3,134 & 3,143 & 2,582 & $21,99 \%$ & $24,09 \%$ & $12,86 \%$ \\
\hline
\end{tabular}

Sumber : Data sekunder yang sudah diolah (2017) 
INOBIS: Jurnal Inovasi Bisnis dan Manajemen Indonesia

Volume 1, Nomor 2, Maret 2018

Sri Dwiningsih, SE., MM

Dari hasil diatas, dapat disimpulkan bahwa kinerja keuangan 6 (enam) perusahaan yang bergerak dalam sektor Property \& Real Estate yang masuk dalam perusahaan LQ45 selama 2 tahun berturut-turut yaitu Pebruari tahun 2015 s/d Januari 2017 periode 2013 - 2015, PP (Persero) Tbk menjadi perusahaan dengan kinerja keuangan perusahaan yang paling baik jika dibandingkan dengan perusahaan property \& real estate lain periode tahun 2013-2015. Sedangkan prestasi kinerja terendah adalah Lippo Karawaci Tbk dengan tingkat ROE terendah dibanding perusahaan property \& real estate yang lain, walaupun omzet yang dihasilkan besar tetapi ada penurunan yang sangat drastis pada tahun 2014 jika dibandingkan dengan tahun 2015. Adapun urutan kinerja yang dihasilkan dari keenam perusahaan property \& real Estate adalah sebagai berikut:

1. (PTPP) Pembangunan Perumahan (Persero) Tbk

2. (PWON) Pakuwon Jati Tbk

3. (BSDE) Bumi Serpong Damai

4. (ASRI) Alam Sutera Reality Tbk

5. (WSKT) Waskita Karya (Persero) Tbk

6. (LPKR) Lippo Karawaci, Tbk

\section{Kesimpulan dan saran}

\section{A. Kesimpulan}

Berdasarkan hasil penelitian untuk mengetahui kinerja keuangan 6 (enam) perusahaan yang bergerak dalam sektor Property \& Real Estate yang masuk dalam perusahaan LQ45 selama 2 tahun berturut-turut yaitu Pebruari tahun 2015 s/d Januari 2017 periode 2013-2015, dengan menggunakan analisis Du Pont System periode tahun 2013-2015 dapat disimpulkan sebagai berikut:

1. Dari hasil pembahasan diketahui hasil Net Profit Margin (NPM), Total Asset Turnover (TATO), Return On Investment (ROI) dan Return On Equity (ROE).

Dari 6 (enam) perusahaan yang bergerak dalam sektor Property \& Real Estate yang masuk dalam perusahaan LQ45 selama 2 tahun berturut-turut yaitu Pebruari tahun 2015 s/d Januari 2017 periode 2013-2015 pada dasarnya keenam perusahaan mempunyai kinerja yang baik dimana dibuktikan bahwa dari keenam perusahaan Property \& real Estate tersebut masuk dalam daftar perusahaan LQ45 selama 2 tahun berturut-turut yaitu Pebruari tahun 2015 s/d Januari 2017, dimana jika bisa masuk dalam perusahaan LQ45 adalah perusahaan2 yang telah terpilih di Bursa Efek Indonesia dengan nilai saham yang stabil \& kinerja keuangan yang baik, dan telah terbukti dari hasil penelitian analisis keuangan pada penelitian ini.

Terlihat dari nilai Net Profit Margin (NPM) perusahaan, hasil NPM Bumi Serpong Damai yg paling besar yaitu senilai 53,40\% sedangkan hasil NPM terkecil adalah Waskita Karya (Persero) Tbk yaitu senilai 5,36\%. Dalam hal ini Bumi Serpong Damai adalah perusahaan yang sangat memuaskan kinerja keuangannya yang hasilnya lebih besar dari rata-rata industry property \& real estate yang lain.

Dari nilai Total Assets Turnover (TATO) Alam Sutra Reality. Tbk menjadi perusahaan dengan hasil TATO terendah yaitu sebesar 0,206 dari beberapa perusahaan property \& real estate yang lain. Sedangkan hasil tertinggi dicapai oleh PP (Persero) yaitu sebesar 0,844. Sehingga dapat dikatakan bahwa perusahaan dengan TATO terendah kurang efisien dalam menggunakan seluruh total aktiva untuk menghasilkan volume penjualan. 
INOBIS: Jurnal Inovasi Bisnis dan Manajemen Indonesia

Volume 1, Nomor 2, Maret 2018

Sri Dwiningsih, SE., MM

Hasil ROI terpengaruh dari hasil NPM \& TATO, hasil dari ROI terendah Waskita Karya (Persero) Tbk yaitu sebesar 3,88\% dan yang tertinggi adalah Pakuwon Jati. Tbk yaitu sebesar $11,73 \%$. Dilihat dari nilai ROI keenam perusahaan tersebut, dapat disimpulkan bahwa Waskita Karya (Persero) Tbk mempunyai tingkat pengembalian yang paling rendah atas nilai yang diinvestasikan dalam aktiva guna memperoleh laba. Sedangkan Pakuwon Jati. Tbk dinyatakan mempunyai kinerja keuangan yang baik sebab nilai ROI berada di atas rata-rata industry walaupun nilai setiap tahunnya dari tahun 20132015 mengalami ketidakstabilan/fluktuasi.

Nilai Equity Multiplier (EM) digunakan untuk menghitung nilai ROE, hasil dari perbandingan keenam perusahaan property \& real estate dapat disimpulkan bahwa Lippo Karawaci Tbk memiliki hasil terendah yaitu sebesar 11,41\% \& PP (Persero) memiliki hasil tertinggi yaitu sebesar 34,09\%.

2. Kinerja keuangan 6 (enam) perusahaan yang bergerak dalam sektor Property \& Real Estate yang masuk dalam perusahaan LQ45 selama 2 tahun berturut-turut yaitu Pebruari tahun 2015 s/d Januari 2017 periode 2013 - 2015, PP (Persero) Tbk menjadi perusahaan dengan kinerja keuangan perusahaan yang paling baik jika dibandingkan dengan perusahaan property \& real estate lain periode tahun 2013-2015. Sedangkan prestasi kinerja terendah adalah Lippo Karawaci Tbk dengan tingkat ROE terendah dibanding perusahaan property \& real estate yang lain, walaupun omzet yang dihasilkan besar tetapi ada penurunan yang sangat drastis pada tahun 2014 jika dibandingkan dengan tahun 2015 . Adapun urutan kinerja yang dihasilkan dari keenam perusahaan property \& real Estate adalah sebagai berikut:

1. (PTPP) Pembangunan Perumahan (Persero) Tbk

2. (PWON) Pakuwon Jati Tbk

3. (BSDE) Bumi Serpong Damai

4. (ASRI) Alam Sutera Reality Tbk

5. (WSKT) Waskita Karya (Persero) Tbk

6. (LPKR) Lippo Karawaci, Tbk

\section{B. Saran}

Berdasarkan dari kesimpulan diatas, maka penulis dapat memberikan saran sebagai berikut:

1. Lippo Karawaci Tbk dilihat dari nilai ROI dan ROE perusahaan yang relatif kecil, hendaknya dapat diperbaiki dengan cara meningkatkan marjin laba bersih perusahaan melalui meminimalisasi biaya operasional, administrasi maupun produksi. Selain itu juga setidaknya mencari alternatif pemasaran yang tepat sehingga dapat meningkatkan volume penjualan di tahun-tahun berikutnya. Perusahaan juga perlu melakukan efisiensi hutang dan total aset.

2. Saran kepada para peneliti selanjutnya yang akan melakukan penelitian terkait analisis kinerja keuangan, hendaknya bisa menggunakan metode yang lainnya, namun jika menggunakan metode yang sama bisa menambahkan periode yang diteliti atau juga bisa dikombinasikan dengan metode-metode lainnya yang bisa memperdalam penilaian kinerja keuangan perusahaan. 
INOBIS: Jurnal Inovasi Bisnis dan Manajemen Indonesia

Volume 1, Nomor 2, Maret 2018

Sri Dwiningsih, SE., MM

\section{Daftar pustaka}

Arikunto,S 2006. Prosedur Penelitian Suatu Pendekatan Praktek, Edisi Revisi, Jakarta: Rineka Cipta.

Elisabet, M Rifa'i, Warter (2014). Mengukur Kinerja Keuangan perusahaan dengan Metode analisis Du Pont System, Studi pada PT. Holcim Indonesia Tbk yang terdaftar di Bursa Efek Indonesia periode tahun 2013-2015 jurnal skripsi manajemen Malang

Fahmi, Irham (2013). Analisis Laporan Keuangan. Bandung : Alfabeta

Harahap, SofyanSyafri. 2002. "Analisa Kritis Atas Laporan Keuangan”. Jakarta : PT Raja GrafindoPersada.

Harahap, Sofyan Syafri. 2007. Teori Akuntansi. Jakarta : PT Raja Grafindo Persada.

Hasan, M. Iqbal, 2002. Pokok - pokok materi metodologi penelitian dan aplikasinya. Bogor : Ghalia Indonesia.

Kasmir, (2008). Bank dan lembaga keuangan lainnya. Edisi Revisi. Jakarta : PT. Raja Grafindo Persada.

Kasmir, (2010). Pengantar Manajemen Keuangan. Edisi Pertama. Jakarta : Kencana.

Kasmir, (2012). Analisis Laporan Keuangan. Jakarta : PT Raja Grafindo Persada.

Munawir. 2004, Analisa Laporan Keuangan, Edisi Keempat, Cetakan Ketiga belas, Yogyakarta: Liberty

PT. Bursa Efek Indonesia. www.idx.co.id

Sudana, I Made. 2009. Manajemen Keuangan Teori dan Praktik. Surabaya : Airlangga University Press.

Sugiyono, 2016. Metode penelitian kuantitatif kualitatif dan $R \& D$. Bandung : Alfabeta

Wahyuni, Tri (2007). Analisis Du Pont System sebagai pengukur kinerja keuangan pada PT. Indofood Sukses Makmur Tbk. Jurnal Skripsi. http://eprints.ums.ac.id/10997/ 